\title{
The Exploration of Reasons Why Southeast Asia Countries Have Strong Insecurity About the Rise of China*
}

\author{
Lyu xiaoli, Bai Ruixin \\ Beijing Normal University, Beijing, China
}

\begin{abstract}
The word, “China' rise”, has highlighted the rapidity and suddenness of China's development, and the Southeast Asia region, both in history and in reality, has a close relationship with China. In face of the giant's rise, some Southeast Asia countries have reduced their sense of certainty and control over this external environment, which causes their insecurity. The reasons of this phenomenon include the factor of history, ideology, geopolitics, overseas Chinese and extraterritorial states intervention. We should go start with national and ideological barriers, combine the analysis of the sense of certainty and control, to understand the underlying causes of insecurity.
\end{abstract}

Keywords: the rise of China, Southeast Asia, the sense of certainty and control, the reasons

\section{Introduction}

The sense of security, which depends on the subject's perception and judgment to the object, is a kind of subject feeling for security, and is the subject's feeling and presentiment towards the danger or risk that already appeared or may appear. The sense of certainty and the sense of control is the main manifestation, like the following description.

One side is the sense of certainty. There are many researches on the sense of uncertainty in the field of medical psychology, and Stanley Budner, the professor of New York State Psychiatric Institute, has described the sense of uncertainty as the tolerance perception of uncertain events, and the cognition would appear when the subject cannot properly classify, perceive, and predict the object. The sense of uncertainty can be positive or negative, which depends on how the subject treats the trend of future: the sense of insecurity would happen when the future is treated as more threatened; the sense of curiosity or expectation when more beneficial (Budner, 1962).

Another side is the sense of control. The famous American psychologist Rotter has pointed that the sense of control is the evaluation and judgment of the role of the individual capability in the influence and decision on the development of external events (Rotter \& Phrares, recited from Yu, 2011). To put it simply, that is the subject that thinks how much he/her can control the influence of the object. Rotter has also divided control into internal and external control: the former' subject attributes controllable factors to internal ones, and thinks self is the creator of life; the latter' subject attributes controllable factors to external ones, and external forces are a major factor in the future.

\footnotetext{
* Financed by National Social Science Foundation (Project No. 14CGJ013).

Lyu Xiaoli, PhD, Associate Professor, School of Government, Beijing Normal University.

Bai Ruixin, Master Degree Candidate, School of Government, Beijing Normal University.
} 


\section{The Internal Logic of National Insecurity}

Generally speaking, the sense of security refers specifically to a person's perception, while in the field of international relations, the sense of national security means the perception of the "nation". However, the nation (state) is not an entity; it is more of a conceptual existence, or it is a concept that people construct according to need. Barry Buzan points out in People, Country, and Fear that the state firstly exists as a social political phenomenon rather than a physical phenomenon. The state is more of a concept shared by the group than a physical body, and to explore the nature of the country from this perspective provides an important clue for us to understand the concept of national security (Buzan, 2009).

As a concept, from the historical process point of view, a country is a concept of groups consisting of single persons, and there are two main ways of existence for this group-ethnic groups and ideological groups (Buzan, 2009). Ethnic groups are different from other political groups. They are formed by people naturally living together. People of the same ethnic group share common or similar historical memories, lifestyles, languages, religions, and spiritual qualities. We can regard the ethnic group as a collectivized individual and the individual as an individualized ethnic group. In order to continue their existence, the ethnic group maintains its own security and development through a series of military, political, and economic systems, and at the same time deals with other groups. Then the concept of the country is gradually formed. But at the same time, the country has also constructed the ethnic. As the formation process of a country is often influenced by many factors, there are often multiple ethnic groups in the same country. "Highest in the country", the feature of national sovereignty requires that all ethnic groups in the country integrate to a certain extent, rather than opposing each other. In summary, we can determine the analytical logic of "individual-ethnic(nation)-state" and analyze the concept of country from the perspective of ethnic. In addition to the main group forming of the country, ideological groups are also a form. Broadly speaking, ideological groups refer to groups that share a common ideology. Therefore, an ethnic group is also an ideological group. Narrowly speaking, it refers specifically to groups that hold a certain political ideology, such as fascism, pluralism, communism and so on. Taking the Soviet Union as an example, the Soviet Union is based on the ideology of communism. The entire Soviet people can be seen as a "communist ethnic group". When in 1991 the Soviet Union people questioned this ideology in general, the foundation of the existence of the "ethnic group" was shaken and the collapse of the "communist ethnic group" led to the dissolution of the concept of the "communist state". It is the irreparable disintegration of the Soviet Union. Ethnic and ideological factors often work together in the process of constructing national concepts, rather than being separated from each other. For example, Nazi Germany is a mixture of fascism and extreme nationalism. The values of the American nation, and the freedom, and democracy are the support of the United States. The common beliefs of people within an ethnic group are also the ideology that guides the nation's production and life. Most countries in the world today are distinguished from each other through ethnics and ideologies. It is worth noting that because of the ethnic's role in countries building, the ethnic groups we talked about here should be a collection of all citizens in the country. It is a collection of national and national minorities, such as the American nation and the Chinese nation. This nation will be called "Guozu” (nation). ${ }^{1}$

\footnotetext{
${ }^{1}$ In China, the meaning of "nationality" and "ethnicity" is quite consistent. As early as when Sun Yat-sen proposed "Three People’s Principles", "nation” is the meaning of "nationality” and it has been used so far. Therefore, the word "nation” is still used in this article.
} 
In summary, we can say that the main body of national insecurity is ethnic groups and ideological groups. Of course, as mentioned before, neither of these is absolutely fragmented. The sense of certainty and control of ethnic groups and ideological groups on the external environment are the main factors that determine their insecurity.

From the perspective of constructivism theory, the power of ideas is enormous, and social reality cannot be independent of human subjective knowledge. The external actions of the country are governed by specific people. The sense of national security mainly refers to the recognition and judgment of national and ideological groups $^{2}$ within the country on the dangers or risks of the external environment and its changes. This cognitive is not only affected by the historical influence, but also depends on the external environment of the reality. It also depends on the sense of certainty and control to the external environment.

The sense of insecurity in the country means that the country lacks a sense of security with regard to the external environment and its changes, and believes that the country is in or about to be in a state of threatened security. In his book, Politics Among Nations, Morgenthau mentioned "insecurity" when talking about "collective security". He pointed out that "the most commonly declared and actually common armament motive is fear of attack, which is also a sense of insecurity.” (Morgenthau, 1990, p. 530) Morgenthau believes that insecurity is an intrinsic motivation for the country's development of armaments. Therefore, people hope to establish a "collective security" mechanism to reduce the country's sense of insecurity and achieve the goal of maintaining peace. Similar to Morgenthau's argument, the "security dilemma” theory states that "the insecurity from mutual suspicion and mutual fear drives these power units to compete for greater power in order to obtain greater security." (Ren, 2006, p. 37) The sense of insecurity in the "security dilemma" is more caused by the distrust between two countries with disparity in strength, emphasizing the mutual security of the two parties in the "security dilemma", and the feeling of insecurity in China in Southeast Asian countries is more unilateral suspicions and fears.

Through the expressions such as "fear", "suspicion", and "distrust”, we should recognize that the national sense of certainty and control is the origin of security issues. For example, assuming there are two countries, A and $\mathrm{B}$, and country A does not know the basic situation of country B, it will have a strong sense of uncertainty, unable to understand and predict the basic attitude and foreign policy of country $\mathrm{B}$, and then produce a strong sense of insecurity, and the external performance is a mistrust of country B; if country A knows the military strength and scientific and technological level (hard power) of country B, and judges that the military and technological level of country B is equal or even more than itself, and the controllability of country B will decline and its insecurity will increase. However, in reality, it is impossible for a country to thoroughly understand another country, especially when it comes to military secrets and strategic intentions. Therefore, there is no absolute sense of certainty and controllability. In a certain sense, it is not easy to eliminate insecurity. Feeling or pursuing absolute security is unrealistic.

\section{The Status of Insecurity in Southeast Asian Countries}

Southeast Asia is located in Southeast Asia, mainly composed of the Indochina, Peninsula, and the Malay Archipelago, a total of 11 countries, most of which have close contacts with China, whether in ancient China or

\footnotetext{
${ }^{2}$ Ethnic groups and ideological groups are mainly embodied in groups that hold state power and citizens in the country. Therefore, the attitudes of ethnic groups and ideological groups often manifest themselves in the official statements of a country, public opinion in general, and so on.
} 
in modern times, the "To the Nan Ocean" refers to the activities of the Chinese people in Southeast Asia. On the background of the rise of China, the emergence of insecure feelings in some countries in Southeast Asia, the subject of it refers to some countries in Southeast Asia, and the object is the rising China. Some countries that have a clear sense of insecurity to China mainly refer to the Philippines, Malaysia, Indonesia, Vietnam, Thailand, and Singapore. This does not mean that other Southeast Asian countries have no sense of insecurity at all, but that the sense of insecurity to the rise of China in those countries is relatively more pronounced. Since the state is essentially the concept of ethnic groups and ideological groups, while both of them are mainly embodied in groups that hold the state power and citizens within the country, Therefore, inspecting the insecurity of a country should start with the country's official position and public opinion, mainly in terms of both words and actions.

In terms of words, the influence of the rise of China on Southeast Asian countries has clearly manifested two aspects of fear. On the one hand, it is the South China Sea issue; on the other hand, it is an economic issue. Therefore, its related words or cognition has also focused on the two aspects. As far as the South China Sea issue is concerned, the sense of certainty and controllability of Southeast Asian countries is obviously lower. At the beginning of the 21st century, the Philippines believed that "China's insistence on excessive demands on the South China Sea or islands makes people doubt its guarantee of non-expansion.” (Yee \& Storey, 2002, p. 250) The commander of the Malaysian National Defense Force pointed out: "In the current circumstances, the biggest problem in regional security is to resolve the issue of the ownership of Nansha and the Xisha Islands, and whether China will use the military to achieve its territorial claims." 3 For Indonesia, "China continues to be regarded as the biggest and potential direct threat to Indonesia's sovereignty... Indonesia's concern about China's territorial revivalist agenda has touched on its inherent natural fragility, which is caused by the potentially disintegrated islands."(Lever, 2001, p. 118) On the economic side, Southeast Asian countries are more worried about their interests in dealing with China. The Philippines believes that although Philippine-China trade will bring great benefits to the Philippines' electronic components, tropical fruits, agricultural exports, and tourism, while at the same time, China has also stolen the harvest of its footwear, apparel, and Christmas products. Indonesia believes that "the trade relationship between China and ASEAN is fundamentally competitive rather than complementary... In the short term, Indonesia should treat its economic integration with China very cautiously."

In terms of related actions, the sense of insecurity in some Southeast Asian countries is mainly reflected in the related meetings, defense, and the actions of regional organizations. Ian Stoll, a senior researcher at the Southeast Asia Institute, said that in view of the rise of China and doubting about whether the United States can maintain its military presence in Asia, the region (Southeast Asia) countries "generally feel strategic uncertainty.” According to the report of the International Institute for Strategic Studies, as of 2012, Malaysia has two "Squid" class submarines, and Vietnam is purchasing six "Kilo" class submarines from Russia. Thailand also plans to purchase submarines, and the "Gripen” fighters it purchased from Saab in Sweden will eventually be equipped with the company's RBS-15F anti-ship missiles. Singapore has invested in the purchase of the F-15SG jet fighter aircraft manufactured by Boeing and purchased two "Shooter" class submarines from Sweden to supplement the four "Challenger" class submarines it already has, enhancing its naval and air force

\footnotetext{
3 Jane's Defence Weekly, September 26, 1992.

4 “China-ASEAN Free Trade: Lessons for Indonesia.” Jakarta Post, Jan. 11, 2002.
} 
capabilities. $^{5}$ On April 28, 2014, the Philippines and the United States formally signed an agreement to strengthen defense cooperation. The Philippines will allow US troops to use the Philippine military base and allow the US military to expand its deployment in the Philippines. ${ }^{6}$ On October 9, 2011, Japan's "Daily News" reported that the Ministry of Defense of Japan is currently studying issues related to the provision of military assistance to Southeast Asian countries and sought cooperation between the United States and Australia. At the Japan-ASEAN deputy ministerial-level defense consultation meeting held in Tokyo, Japan, ASEAN countries all requested that Japan provide them with the SDF's demining and unexploded bomb disposal technologies.

In the related actions of Southeast Asian countries, we cannot prove that it was triggered entirely by the rise of China, the reason for which may be that Southeast Asian countries adopt the strategy of "balancing the great powers", and that is, the introduction of forces such as the United States, Japan, and China, which would enable it to achieve a strategic equilibrium and maintain stability in Southeast Asia; the reason may be that special geographical advantages and resource advantages in Southeast Asia, and the advantages of shipping ports and abundant resources make this place a hot spot for powers of great powers, and the erosion of the war in Southeast Asia during World War II; After entering the new century, Japan, the United States, China, India, and other powerful forces wrestle in Southeast Asia; the reason may be that Southeast Asia countries have a rapid economic development, seeking an autonomous defense system; the ASEAN, a major regional integration organization in Southeast Asia, has gradually grown and expanded, gradually forming a political, economic, and security integrated cooperation organization based on economic cooperation and establishing a series of cooperation mechanisms. The above reasons may lead Southeast Asian countries to strengthen their defense forces and seek their own security. However, from the official positions of some Southeast Asian countries mentioned above and the views of relevant scholars, it is not difficult to see that the rise of China's giants has obviously had a great impact on them.

\section{Reasons for Insecurity in Southeast Asian Countries}

The rise of China is a trigger for Southeast Asian countries to create insecurity to China. However, this does not mean that rapidly developing China will inevitably pose a threat to the security of Southeast Asian countries. In fact, both in terms of history and reality, China is characterized by restraint and its expansion is not strong. In modern history, China and many Southeast Asian countries were all victims of colonialism. In World War II, they were also victims of fascism. In Central Asia, which is also close to China, the response of it to China's rapid development is not as strong as some Southeast Asian countries. For example, in 2014, the United States' Manas Air Force Base in Kyrgyzstan, the most important military base in Central Asia, was closed on June 3. At the same time, the "SCO Group" that China, Russia, and Central Asian countries have participated in has also become an important organization for maintaining regional security. With the launch of the "One Belt and One Road”, China's economic and trade cooperation with Central Asian countries is also heating up. It can thus be seen that the sense of insecurity created in some countries in Southeast Asia in relation to the rise of China has its own particularities, and it has a very strong sense of uncertainty and uncontrollability in many aspects of rising China. Specific can be summarized as historical factors, ideology,

\footnotetext{
5 "The Southeast Asian countries are purchasing advanced weapons to cope with the rise of China." China News, October 9, 2012, http://www.chinanews.com/mil/2012/10-09/4232084.shtml.

6 "The United States and the Philippines formally signed the Agreement on Strengthening Defense Cooperation and Allowed the United States to Use the Philippine Base.” Global Internet Military, April 28, 2014, http://mil.huanqiu.com/world/2014-04/4982280.html.
} 
geopolitics, economic factors, overseas Chinese issues, intervention of major countries.

First it is historical factors. The historical factor is a national factor to a certain extent, because history is often the history of the formation and development of the nation. Chinese ancient dynasties often had disputes with Southeast Asian countries. The reason is as follows: First, although the ancient Chinese dynasties were introverted in most cases, and they maintained a tributary relationship with neighboring countries, this vestigial relationship originally requiring each other, and that is, neighboring small countries met their own economic interests, and the Chinese dynasty met the psychological needs of its "Celestial Empire”; however, China's identity as a sovereign country also interfered with the internal affairs of vassal state from time to time. This often caused disputes between Chinese dynasties and neighboring countries. For example, Song Yue's "White Tengjiang Battle” in 981 was caused by a coup in Vietnam's court and the Song Dynasty sent troops to cut off rebellion; In 1406, the Ming Dynasty army was abducted by the Vietnamese Hu Dynasty army when the aristocrat Chen Tianping returned to the throne at the Ming Dynasty army's escort, and Yongle Emperor got furious, he recruited troops to fight with Vietnam, known as "Nan Zheng An Nan", etc. Second, after the independence of the feudal dynasties in Southeast Asia (especially the Indochina Peninsula), they often invaded the southwest border of China, and the Chinese ancient dynasty thus fought against these countries. Such as the 1075 Song Dynasty Xining War, that is Vietnam's invasion of the Northern Song Dynasty Guangnan West Road and the counterattack war of the Northern Song Dynasty against the Vietnam Li Dynasty; During the Wanli period of the Ming dynasty, the Myanmar's voyage to the north of the Ming Dynasty invaded the territory of the Ming dynasty in the southwest and caused the counterattack of the Ming dynasty. Thirdly, in the Yuan and Qing Dynasty which was dominated by national minorities and the powerful dynasty of the Ming, China had the initiative to invade parts of Southeast Asia and even conquered some countries. The Yuan dynasty attacked Vietnam Chen dynasty in 1258, 1285, and 1287 to 1288, and attacked Burma in 1277, 1283 to 1285, and 1300 to 1301, and they traveled to Java from 1293 to 1294. In the early years of the Ming dynasty, which was strong, Vietnam was ruled for 20 years, and was subsequently expelled from Vietnam by Levi, the founding monarch of the Lebanese Empire. From 1555 to 1606, the Ming Dynasty and Burma’s Dong Yu dynasty conducted a protracted war. The Qing Dynasty fought against the dynasty in Myanmar four times in 1765, 1766, 1768, and 1770 respectively. And there was the war between the Qing Dynasty and Vietnam from 1788 to 1789 (China called "The Battle of Annan”). These show that the contradictions between China and Southeast Asian countries have continued in history, and disputes between dynasties have occurred from time to time, and the national heroes of many countries in Southeast Asia emerged from resisting aggression of the Chinese dynasty, which has an important influence on national sentiments and national memory. After the modern period, however, China's influence on Southeast Asia has gradually decreased. After the founding of New China, China's participation in Southeast Asian affairs was limited, mainly about issues such as national liberation and ideology. For example, in 1950, China participated in Vietnamese war of resistance against France; in 1965, China attended the War to aid Vietnam and resist America. However, due to the limitation of national power and the strong involvement of the United States, the sense of insecurity that Southeast Asian countries have had for the new China has not been so strong, and what has changed more is the recognition of the communist movement. For instance, during the Cold War, when the United States gave Thailand great economic and military assistance, the United States instilled the ideology of anti-communism and anti-China ideology in order to induce Thailand to resist the "communist movement”. An official in Thailand stated that they should not have accepted the ideology of the United States in the beginning: we were led to believe that 
communism is evil, China is a "yellow" evil, Vietnam is evil, mostly because of US propaganda. They were just like demons, threatening all countries in Southeast Asia (Blaxland, \& Raymond, 2017). Until the 21st century, the rise of China made Southeast Asian countries see the shadow of the Chinese dynasty once again. The neutral development slogans such as "harmonious world" and "the great rejuvenation of the Chinese nation" put forward by China are also easily interpreted by Southeast Asian countries as an attempt by China to recall the past dynasties and restore the previous tributary system.

Second, it is ideological factors. The ideological problem can be seen as a deep-seated reason for the gap between China and some Southeast Asian countries. In September 1954, the United States, the United Kingdom, Australia, New Zealand, the Philippines, Thailand, and Pakistan established the Southeast Asia Collective Treaty Organization (SEATO). The organization, together with the Baghdad Treaty Organization and the North Atlantic Treaty Organization, constitutes the encirclement of the blockade of the communist movement to suppress the regional national liberation movement and the communist movement. This has also created the fear and exclusion of the socialist ideology in Southeast Asia. Some countries have formed a tradition of terrorism and anti-communism. During the "Cultural Revolution", China's "Left" thought interfered with China's foreign relations. The Southeast Asian countries themselves have experienced political instability due to the intensification of contradictions at home and abroad. For example, in 1960, a coup d'état occurred in Laos; there were a military coup in Burma in 1962 and the armed uprising of the People's Party of Brunei in the same year; in Thailand, where there was no communist armed struggle in 1964, armed struggle and armed bases have also emerged (Sun, 1994). In the 1970s, China's support for the Cambodia's Khmer Rouge regime also deeply impressed China with the "revolutionary output". After the end of the Cold War, although ideological issues gradually faded, the ideological gap did not dissipate. On December 23, 2016, US President Barack Obama signed the Portman-Murphy Counter-Propaganda Bill. The bill is a supporting act of the 2017 National Defense Authorization Act, which aims to "help the United States and its allies counteract political propaganda from foreign governments such as Russia and China", and the adoption of anti-foreign propaganda law indicates that the United States' "Speech Power strategy" will return to the "ideological war" in the Cold War from the "imperceptibly influence" after the Cold War. ${ }^{7}$ Western countries generally view socialist China as "economically changing politics". With the transformation of China's economic system, the middle class continues to grow and China's politics will shift toward the direction of Western democracy. However, in fact, China has embarked on a path of socialism with Chinese characteristics that suits its national conditions. This is contrary to what many Western countries expected. China's development model is different from the western capitalist model. This is also the reason why the capitalist world cannot see or feel the prospects for China. For Southeast Asian countries, this uncertainty is an important reason for their sense of insecurity about the rise of China.

Third, it is geopolitical factors. The South China Sea issue and the theory of "filling vacuum" are two major factors that have created insecurity in some countries in Southeast Asia. The South China Sea spans about 2,000 kilometers and crosses about 1,000 kilometers. China calls it "South Sea". Vietnam calls it the "East Sea”; the Philippines calls it the "Western Philippines Sea”; Singapore, Malaysia, Indonesia, and other countries call it "South China Sea”. Countries such as Vietnam, the Philippines, Malaysia, and Brunei all claim

\footnotetext{
7 “Obama Beats Imaginative New War through Anti-Foreign Propaganda.” before Obama step down, Sina Military, December 30, 2016, http://mil.news.sina.com.cn/dgby/2016-12-30/doc- Ifxzczff3433047.shtml.
} 
sovereignty over the sea. In dealing with the South China Sea issue, Southeast Asian countries have adopted strategies such as armed occupation, joint against China, and internationalization of the South China Sea issue. China, on the other hand, advocates peaceful settlements, friendly consultations, and opposition to complicating and expanding disputes. The strategy for dealing with the South China Sea issue between the former and the latter is fundamentally contradictory. Especially under the background of the continuous progress of the Chinese navy's power, Southeast Asian countries cannot determine how China will solve the South China Sea issue, but also feel uncontrollable about the possible deterioration of the South China Sea. In particular, Vietnam, the Philippines, Brunei, Malaysia, and other countries that have disputes with China in the South China Sea are worried that China will use force to solve the South China Sea issue, and the China's proposal of "shelving disputes and joint development" is not supported, and from time to time these countries cater to Western countries' speculation on the "China threat theory" (Cheng, 2002). After the disintegration of the Soviet Union in the 1990s, the decline in US strategic focusing on Southeast Asia led to a "power vacuum" in Southeast Asia, ASEAN's power in defense and regional security affairs was still weak, and regional powers such as China, India, and Japan's status continued to rise. This has created a great sense of insecurity among Southeast Asian countries in "filling the vacuum" from any other country. The power vacuum in the field of international relations is rooted in the theory of realism, that is, countries are chasing power in the international community. The concept itself is aggressive and controlling. It is a concept left over from the colonial period. And it embodies the control of powerful countries outside the region on weaker regions and the mastery of their resources. During the period of colonialism, western powers divided up the world and built their own development and progress on the crushing and looting of colonial people. After entering the 21st century, Western countries still use old eyes to view cooperation between emerging market economies and other countries. They believe that countries like China are taking the old road of western colonialism (the so-called "new colonialism”) and exploiting and plundering countries such as Africa. For example, on the 4th and 5th of May 2017, the Chinese website of the New York Times launched a series of reports under the theme of “Chinese-style neo-colonialism?”, which was described many Chinese companies' investment projects in Namibia with a lot of ink and ink and compared China's practices with the United States' post-World War II Marshall Plan. ${ }^{8}$ Since Southeast Asian countries were also the objects of colonialism in modern times, there was always a sense of insecurity in their national memories and they were wary of contact with other major powers.

Fourth, it is economic factors. The most intuitive manifestation of China's rise is China's economic growth. For the first time since China's reform and opening up in 1978, GDP growth has exceeded ASEAN for the first time (the former is $11.6 \%$ and the latter is $7.2 \%$ ); between 1979 and 1981, the growth rate was basically the same; since 1982, China's growth rate was equal to ASEAN's 2 times firstly; until 2014, the growth rate of the two remains roughly at 2:1. China's per capita GDP also exceeded ASEAN for the first time in 2004, and the gap has continued to widen. ${ }^{9}$ Of course, it is the officials and scholars who get more vigilance from these figures. The common people are more likely to feel China's "threat” from actual trade. For example, trade between China and Thailand has caused Thailand's local agriculture to suffer. Dissatisfied with this, even if China agrees that Thailand could exchange dried longan for China's main battle tank, it will not eliminate the

\footnotetext{
8 “U.S. Media Takes ‘New Colonialism’ to Discredit Chinese Experts: Interpretation of Misinterpretation.” Global Internet, May 6, 2017, http:// world.huanqiu.com/exclusive/2017-05/10605964.html?referer =huanqiu.

${ }^{9}$ The relevant data are cited from the website of the United Nations Statistics Division: https://unstats.un.org/home/.
} 
dissatisfaction of Thai farmers (Chambers, 2005, p. 17). During the Asian financial crisis of 1997-1998, China's attitude of maintaining a strong RMB has changed the attitude of Southeast Asian countries. However, this move also shows that China has the ability to influence the export trade of Southeast Asian countries through exchange rate measures (although China does not have such a subjective subjectively). At the same time, due to the economic homogeneity of both China and Southeast Asia (both initially developing export processing industries), it is easy for the two to form a competitive relationship. As China has improved its own scientific and technological level, many Western countries have shifted their investments from Southeast Asia to China, which objectively damages the foreign trade-oriented economy in Southeast Asia. Even countries like Thailand through industrial resources took advantage of the economic development of China, and also found that this relationship was gradually changing. In 2004, related media often reported that Thailand suffered damage due to the slowdown in China's economic development (Chambers, 2005, pp. 16-21). In short, in terms of economy, Southeast Asian countries have more of an uncontrollable sense. Even if the total economic volume of the 10 ASEAN countries still has a certain gap with China, not to mention a separate country, which is worried about China's development.

Fifth, it is overseas Chinese factors. Overseas Chinese refer to Chinese immigrants and their descendants. Due to geographic location and other factors, Southeast Asia has become the most concentrated place for overseas Chinese besides in China. By the early 1950s, the number of Chinese in the world was about 12 to 13 million, and the proportion of Chinese in Southeast Asia was more than 90\%; although the distribution pattern of overseas Chinese has changed since the 1970s, the proportion of overseas Chinese living in Southeast Asia has remained at around $73 \% .{ }^{10}$ Due to the huge number of Chinese and various factors, the Southeast Asian region has always had a tradition of "exclusive Chinese". For example, in 1740 Java (now Indonesia), the "Red Creek tragedy"; in 1967, the Burmese killings; the 1969 Malaysian mob incidents; the 1975 Cambodian Khmer Rouge incidents (ideological colors); the 1977 The Vietnam Incident in Vietnam, and the Indonesia Incident in 1998 (also known as the "Black May Riot”) and so on. As the home country of overseas Chinese, China's relations with Southeast Asian countries are often at a low ebb because of the improper handling of overseas Chinese issues. The rejection of overseas Chinese by local communities in Southeast Asia is largely due to their own sense of insecurity. They fear that Chinese people will snatch away job opportunities from local people and fear that the Chinese will grasp the country's economic lifeline and even the political situation. As early as the 1950s, the United States paid high attention to overseas Chinese in Southeast Asia. The United States recognized that: "Almost all governments of Southeast Asian countries have a feeling of distrust and fear for overseas Chinese, because overseas Chinese never equate their own interests with the interests of the country of residence. This determines that they are very likely to become tools for external subversive forces."11 As an uncertain and uncontrollable factor, overseas Chinese have deepened the sense of insecurity of Southeast Asian countries towards overseas Chinese and their home countries. In addition, because of cultural, economic, and religious beliefs, ordinary people in Southeast Asian countries will also exclude overseas Chinese. In general, overseas Chinese are extremely concerned about the political process and future fate of their home countries. During the War of Resistance against Japan, Southeast Asia established the "South China Association of Overseas Chinese" (the full name "Nanyang Overseas Chinese Association for the Homeland Refugees") and

\footnotetext{
${ }^{10}$ For details: Zhuang Guotu. The historical changes in the number and distribution of overseas Chinese in the world. World History, 2011(05), 4-14.

${ }^{11}$ Guidelines for United States Programs Affecting the Overseas Chinese in Southeast Asia, OCB Report, Dec. 1, 1957.
} 
the Nanqiao Association made great contributions to the Chinese war of resistance from financial and material resources. This extremely high interest correlation between overseas Chinese and China has made Southeast Asian countries full of doubts about the rise of China and the numerous realities of overseas Chinese.

Sixth, it is great power intervention. Southeast Asia is located at the "crossroads" of Asia and Oceania, the Pacific Ocean, and the Indian Ocean. It is rich in natural resources and its strategic position is very important. Therefore, it is also a wrestling field for great powers. In the 18th and 19th centuries, the western powers basically transformed the Southeast Asian region into colonies and divided them up; during World War II, the Japanese fascist forces expanded toward Southeast Asia, expelling the original Western colonial powers from Southeast Asia and replacing them. After the end of World War II, the United States, Britain, and other victors tried again to restore their colonial rule over Southeast Asia. However, with the rise of the national liberation movement, colonial rule became loose and weak, combined with the decline of European powers, the Southeast Asia region was basically controlled by the United States through economic and military affairs. The history of frequent interventions by such great powers has left the peoples of Southeast Asia in a state of lack of security for a long time. The aforementioned factors, whether geopolitical or ideological, or even overseas Chinese, have the participation and encouragement of the United States. Inciting China's peripheral countries to be hostile to China is the main means for the United States to contain China's rise, both in history and in reality. For example, spreading the "China threat theory" in Southeast Asia and even the world, is one of the factors that create a sense of insecurity for Southeast Asian countries in China. With the self-development of Southeast Asian countries, ASEAN has become increasingly mature in handling regional affairs. The United States has gradually reduced its control and exerted more influence instead. Therefore, the impact of great power intervention on Southeast Asian countries will weaken with the development of Southeast Asian integration.

\section{Conclusion}

At present, whether in the official or academic circles, there is less and less mention of the word "China's rise". On the one hand, it is because "China's rise" as a state is no longer new, and China is no longer just focusing on "digital growth", but is paying more attention to the overall layout of the socialist cause with Chinese characteristics. On the other hand, “China's rise” was originally a product of western media's excessive rendering of China's development. Although it describes China's development status to some extent, it is also prejudiced.

However, no matter how we describe China's development, the rise of China has become a fact. The impact of the rise of China on Southeast Asian countries cannot be ignored. We must face the insecurities of the Southeast Asian countries and recognize that the insecurity of some Southeast Asian countries is deeply rooted in its national memory and the ideological group's judgment to the external environment, deeply understand the sense of uncertainty and uncontrollability of the Southeast Asian countries over the rise of China, stand on the position of Southeast Asian countries to think about issues, and look for reasons from several aspects such as history, ideology, geopolitics, economics, overseas Chinese, and intervention by major countries. Only in these ways can we better understand and observe the development and interaction of relations between China and Southeast Asian countries. 


\section{References}

Blaxland, J., \& Raymond, G. (2017). Tipping the Balance in Southeast Asia? Thailand, the United States and China. Canberra: The centre of gravity series.

Budner, S. (1962). Intolerance of ambiguity as a personality variable. Journal of Personality, 30(1), 29.

Buzan, B. (2009). People, country, and fear. Beijing: Central Compilation and Translation Press.

Chambers, M. R. (2005). China and southeast Asia: Creating a "win-win” neighborhood. Washington DC: Asia Program Special Report No.126.

Cheng, X. Y. (2012). Changing and shaping of China's security image in Southeast Asia: Concurrently discussing military soft power and its application. Social Sciences, 33(10), 4-14.

Economy, E. (2005). China's Rise in Southeast Asia: implications for the United States. Journal of Contemporary China, 14(44), 409-425.

Goh, E. (2007). Great Powers and Hierarchical Order in Southeast Asia: Analyzing Regional Security Strategies. International Security, 32(3), 113-157.

Kurlantzick, J. (2006). China's charm offensive in southeast Asia. Philadelphia: Current History.

Lan, S. Y. (2008). Reasons for the influence of Chinese culture on the weakness in southeast Asia from the 11th century to the mid-19th century. Innovation, 2(4), 47-50.

Lever, M. (2001). Indonesia’s Contact with China—Dilemma, Alastair Ian Johnston, Robert Rose, Contact with China—Dealing with a rising power, p. 118.

Li, Y. P. (2004). Relationship between china and southeast Asian countries after the cold war from regionalism. Journal of Xiamen University (Philosophy and Social Science), 79(5), 64-70.

Liu, X., \& Yin, X. H. (2006). Overseas Chinese in southeast Asia in the 1950s and 1960s and US containment policy towards China. Contemporary Chinese History Studies, 13(4), 39-46.

Morgenthau, H. J. (1990). Politics among nations. Beijing: Chinese People’s Public Security University Press.

Ren, X. (2006). Security: A study of conceptual history. Foreign Affairs Review (Journal of Foreign Affairs University), 23(5), 36-45.

Ruan, C. Z. (2009). Southeast Asia's view of a rising China: A security perspective. Shanghai: Fudan University Press.

Ryosei, K., \& Wang, J, S. (2004). China’s changing role in Asia. Japan Center for International Exchange (pp. 3-21).

Schäfer, P. J. (2012). Human and Water Security in Israel and Jordan. Berlin Heidelberg: Springer.

Sun, F. S. (1994). The evolution and development of post-war relations between China and southeast Asian countries. Journal of Foreign Affairs University, 11(4), 9-15.

Wu, Z. C. (2014). Analysis of China's national image in southeast Asia after the cold war. Jinan: Shandong Normal University.

Yee, H., \& Storey, I. (2002). The China threat: Perceptions, myths and reality. London: Routledge.

Yu, C. S. (2013). ASEAN Countries' cognition and policy response to China's rise. Contemporary Asia-Pacific, 22(3), 111-128.

Yu, S. G. (2011). The sense of certainty, the sense of security, the sense of control-The three levels of human security needs. Social Psychology, 26(2), 3-8.

Zhai, K. (2006). Analyzing the "China Threat Theory" in southeast Asia. Asia-Africa Perspectives, 3(5), 52-55.

Zheng, H. F. (2004). Research on China's peripheral relations after the cold war. Jinan: Shandong Normal University.

Zheng, Z. M. (2004). Dispute over the South China Sea under the Asian-Pacific pattern. Party School of the CPC Central Committee. 